\title{
Vegetation and climate change in the Beijing plain during the last million years and implications for Homo erectus occupation in North China
}

\author{
Maotang Cai a,b,c,d,*, Dainan Xu ${ }^{\text {a,b,c }}$, Mingjian Wei ${ }^{\text {a,b,c,*** }}$, Junping Wang a,b,c , Baolin Pan a,b,c \\ a College of Resource Environment and Tourism, The Capital Normal University, Beijing 100048, China \\ b Key Laboratory of Resource Environment and Geographic Information System, Beijing 100048, China \\ c State Key Laboratory Cultivation Base: Urban Environment Process and Digital Module, Beijing 100048, China \\ d Key Laboratory of Land Surface Pattern and Simulation, Institute of Geographical Sciences and Natural Resources Research, Chinese Academy of Sciences, Beijing 100101, China
}

\section{A R T I C L E I N F O}

\section{Article history:}

Received 19 December 2014

Received in revised form 16 April 2015

Accepted 1 May 2015

Available online 9 May 2015

\section{Keyword:}

Beijing

Middle Pleistocene

Homo erectus

Pollen

\begin{abstract}
A B S T R A C T
Beijing is of great significance in human evolution studies. However, the lack of well-dated records of climate and environmental changes, which are frequently cited as important drivers of early human evolution, impede understanding of the evolution and dispersal of humans on the Beijing plain. A 150-m deep drill core was collected from the Changping District of the Beijing plain to reconstruct the changes in vegetation and climate during the Middle Pleistocene using pollen records. The results indicated that the tree genus Ulmus and the herb genus Artemisia were dominant in most of the samples from 0.96 to $0.61 \mathrm{Ma}$, reflecting an open forest steppe covering the Beijing region. Between 0.61 and $0.44 \mathrm{Ma}$, the vegetation communities shifted to an Artemisiasteppe as the tree cover declined. This was followed by a further shift in vegetation community structure to a Chenopodiaceae-Asteraceae steppe between 0.44 and $0.23 \mathrm{Ma}$, followed by the conversion to an ArtemisiaAsteraceae steppe after $0.23 \mathrm{Ma}$. The pollen record revealed a long-term deterioration of the vegetation, which indicated an increasing trend of drying and cooling in the Beijing plain during the Middle Pleistocene. This coincides with the Homo erectus colonization of North China during this period. These findings provide supporting evidence that a shift in climate towards cold and dry conditions during the Middle Pleistocene may have directly benefited Homo erectus populations in open habitats of North China. This general pattern of declining vegetation cover in the study area is consistent with climatic and environmental patterns in other regions of North China, which were probably influenced by global cooling during the Middle Pleistocene.
\end{abstract}

(c) 2015 Elsevier B.V. All rights reserved.

\section{Introduction}

The Beijing plain is located in the northwest region of the North China Plain and its environment is influenced by the East Asian Monsoon circulation (Fig. 1a). Beijing is of great significance in human evolution studies. Fossils attributed to Homo erectus (often referred to as "Peking Man") and plentiful evidence of hominid habitation, including quartzite flakes and choppers, burnt bones, abundant vertebrate fossils and possible ash from fires (Jia, 1980), attest to the occupation of this region during the Middle and Late Pleistocene periods ( $\mathrm{Wu}$ and Dong, 1985). Climate change is commonly considered an important driver of hominin evolution and dispersal patterns (deMenocal, 1995, 2004; Potts, 1996; Maslin and Christensen, 2007). Thus, in an attempt to better understand the local climate and habitat in which early

\footnotetext{
* Correspondence to: M. Cai, Key Laboratory of Land Surface Pattern and Simulation, Institute of Geographical Sciences and Natural Resources Research, Chinese Academy of Sciences, Beijing 100101, China.

** Correspondence to: M. Wei, College of Resource Environment and Tourism, The Capital Normal University, Beijing 100048, China.

E-mail addresses: caimaotang@126.com, caimt@igsnrr.ac.cn (M. Cai), weimj@cnu.edu.cn (M. Wei).
}

humans lived, many paleoclimatological studies have been performed at the "Peking Man" site (Wu et al., 1985; Zhu and Zhou, 1994; Goldberg et al., 2001). However, there are significant disagreements concerning the colonization and living environment of $H$. erectus in this region. Previous studies postulated that $H$. erectus lived in the glacial age (MIS 16) (Ji, 1989), the interglacial age (MIS 15) (Kong et al., 1981; 1985), or during both of these periods (Liu and Wang, 2004). The climate and vegetation transition of the Middle Pleistocene may play an important role in determining the colonization of $H$. erectus. Zhang and Tang (2007) synthesized the archaeological and paleoenvironmental records of the Peking Man site and indicated that the proportions of silvicolous mammals were similar to those of steppe mammals in layer 11 (about $0.66 \mathrm{Ma}$ ), showing a forest-steppe-climate pattern. Next, in layer 7 (about $0.41 \mathrm{Ma}$ ), the vegetation type changed to shrub-steppe. Moreover, Wang et al. (1997) stated that the relatively "cold-climate-adapted" Paleoarctic fauna were not found until the time of the Chenjiawo ( $0.65 \mathrm{Ma})$ and Zhoukoudian (0.5 Ma) hominid relics. However, previous studies only focused on the fossil strata (Kong et al., 1985; Wu et al., 1985; Zhu and Zhou, 1994); therefore, there is currently a lack of both a well-dated and a consecutive record linking hominid habitat in this region to long-term changes in underlying climatic conditions. Such climatic records are crucial in the 


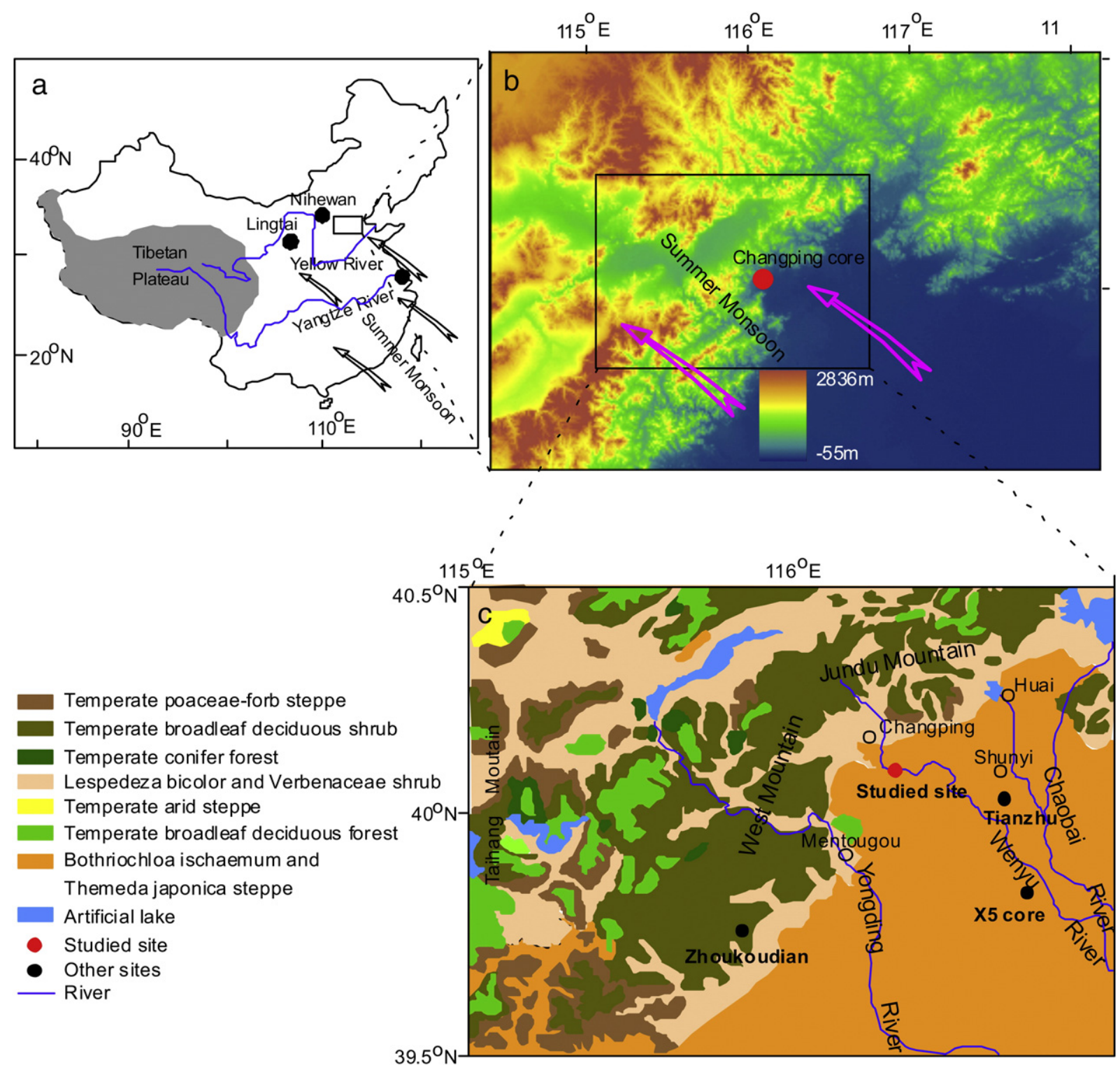

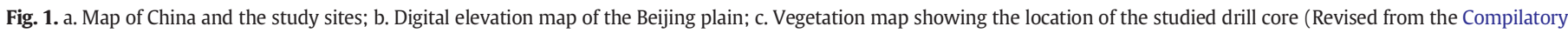
Commission of Vegetation of China, 1980).

continued development of our understanding of the evolution and dispersal of early humans on the Beijing plain.

In the present study, a 150-m drill core was collected from the Changping District of the Beijing plain $\left(40.8^{\circ} 22.6^{\prime} \mathrm{N}, 116.12^{\circ} 17.1^{\prime}\right.$ E) for pollen analyses. The pollen record obtained from the fluviolacustrine sedimentary archives provides important information on regional vegetation that can be used to infer climate changes in North China during the Middle Pleistocene. Such paleoclimatic information is crucial for gaining a comprehensive view of the East Asian Monsoon circulation in North China that can be used to test key theories of early human evolution and expansion in East Asia.

\section{Climate and vegetation of the Beijing plain}

The study area is located in the northwest region of the North China Plain, in the warm temperate and semi-humid continental monsoonal zone. The current regional climate (mean annual temperature of $11.6^{\circ} \mathrm{C}$; average annual rainfall of $585 \mathrm{~mm}$; and mean evaporation of $2080 \mathrm{~mm}$ ) is characterized by cold and dry winters due to the influence of the East Asian winter monsoon that emanates from high-latitude areas. In contrast, the summers are relatively warm and humid under the influence of the East Asian summer monsoon (the rainfall in summer accounts for $75 \%$ of the total annual rainfall) (Fig. 2). Under these climatic conditions, the zonal vegetation is warm temperate deciduous broad-leaved forest and grassland. In the flat area, the vegetation is mainly composed of north temperate elements featuring species of the families Asteraceae, Poaceae, Fabaceae, Rosaceae, Ranunculaceae, Apiaceae, and Brassicaceae. Other taxa include Eurasia steppe elements such as Tribulus terrestris, Salsola collina, Tamarix chinensis, and Suaeda glouca. The flora of the surrounding mountains is divided into three groups with respect to altitude. Below an altitude of $800 \mathrm{~m}$, the scrub-grassland of the Verbenaceae and Rosaceae families dominate the area. The original species, such as Quercus variabilis, Pinus tabulaeformis, and Platycladus orientalis, appear sporadically. From 800 to $1000 \mathrm{~m}$, the vegetation is dominated by Quercus liaotungensis, Pinus tabulaeformis, as well as scrubby Betula platyphylla and Betula albo-sinensis. Over $1000 \mathrm{~m}$, the original species was Larix principis-rupprechtii and Picea, but currently, it is mainly shrubs of Salix caprea, Syringa wolfi, Lespedeza bicolor, Corylus, and Spiraea (Compilatory Commission of Vegetation of China, 1980). 


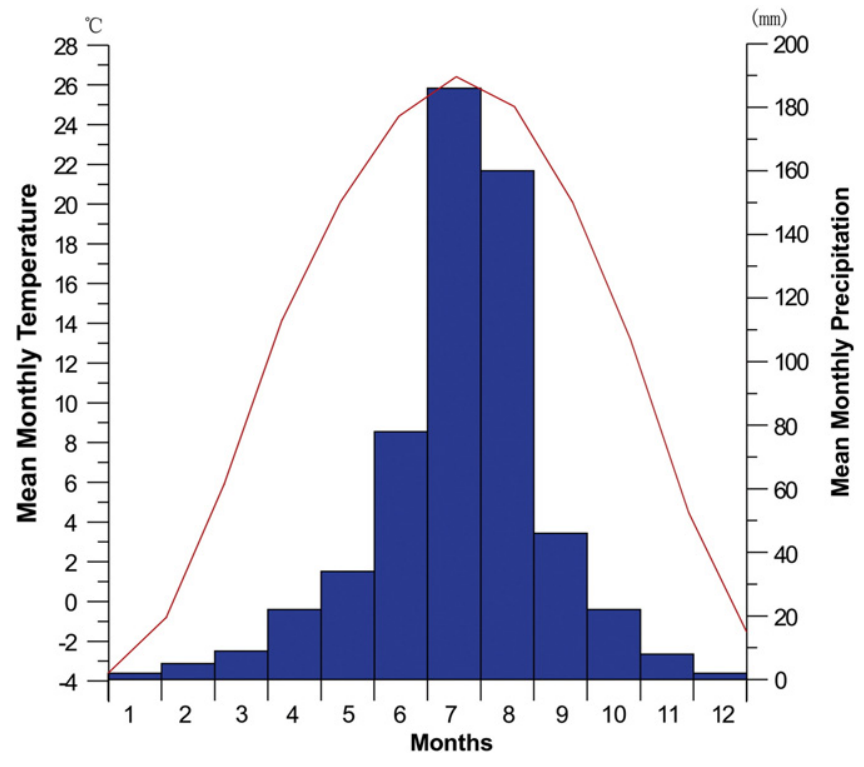

Fig. 2. Mean monthly temperature and precipitation data collected from a Beijing climate station over the period from 1971 to 2000 .

\section{Materials and methods}

A 150-m deep drill core was collected from the Changping region of the Beijing plain $\left(40.8^{\circ} 22.6^{\prime} \mathrm{N}, 116.12^{\circ} 17.1^{\prime} \mathrm{E}\right)$ in 2012 . The lithology of the core is mainly composed of layers of blackish-gray and grayishyellow clay, silty-clay, silt, and a clay/silt layer with a few fine, coarse sand, and gravel layers. In general, the sediments of the core show an alternating sequence of sand and clay-dominated layers (Zhang et al., 2012; Cai et al., 2014).

Prior to laboratory analysis, the core was sub-sampled at $5 \mathrm{~cm}$ intervals. A total of 568 oriented block samples were collected at intervals of $20-25 \mathrm{~cm}$ for paleomagnetostratigraphic study. The magnetostratigraphic results indicate that the Brunhes/Matuyama boundary is at $134.2 \mathrm{~m}(0.78 \mathrm{Ma})$, and the top of the Jaramillo event is at $145.5 \mathrm{~m}(0.99 \mathrm{Ma})$ (Fig. 3). The thermoluminescence (TL) age of the upper sand at $\sim 2 \mathrm{~m}$ is $10.4 \mathrm{ka}$ (Zhang et al., 2012; Cai et al., 2014). Thus, the ages of the Changping core span from $\sim 0.01 \mathrm{Ma}$ (TL results) to $1.07 \mathrm{Ma}$ (extrapolation of magnetostratigraphic dating). Depth-to-age correlations were performed between the main magnetic polarity boundaries and the TL date using average sedimentation rates.

A total of 235 samples were collected at 0.5 1.5 m intervals for pollen and spore analysis. The preparation procedures follow those described by Moore et al. (1991). In brief, 50-150 grams of samples were treated with $10 \% \mathrm{HCl}$ and $39 \% \mathrm{HF}$ to remove carbonates and silica, respectively, and $10 \% \mathrm{KOH}$ to remove humic substances. The samples were then subjected to heavy liquid floatation (gravity between 1.8 and 2.0) followed by mounting in glycerin jelly before microscope examination. All samples were studied at The Capital Normal University (Beijing, China). Palynomorph identification was aided by the reference texts of Song et al. (1999) and others (Xi and Ning, 1994; Wang et al., 1995). Of the 235 total samples, 108 contained more than 100 pollen grains and therefore had a sufficiently high palynomorph content and diversity for subsequent interpretation of floral community structure. The terrestrial sum of the tree, herb and shrub taxa in each pollen spectrum was taken as $100 \%$ for calculating the pollen percentages.

\section{Results}

Approximately 81 species were identified in the core, mainly nonarboreal taxa including Artemisia, Chenopodiaceae, Asteraceae,

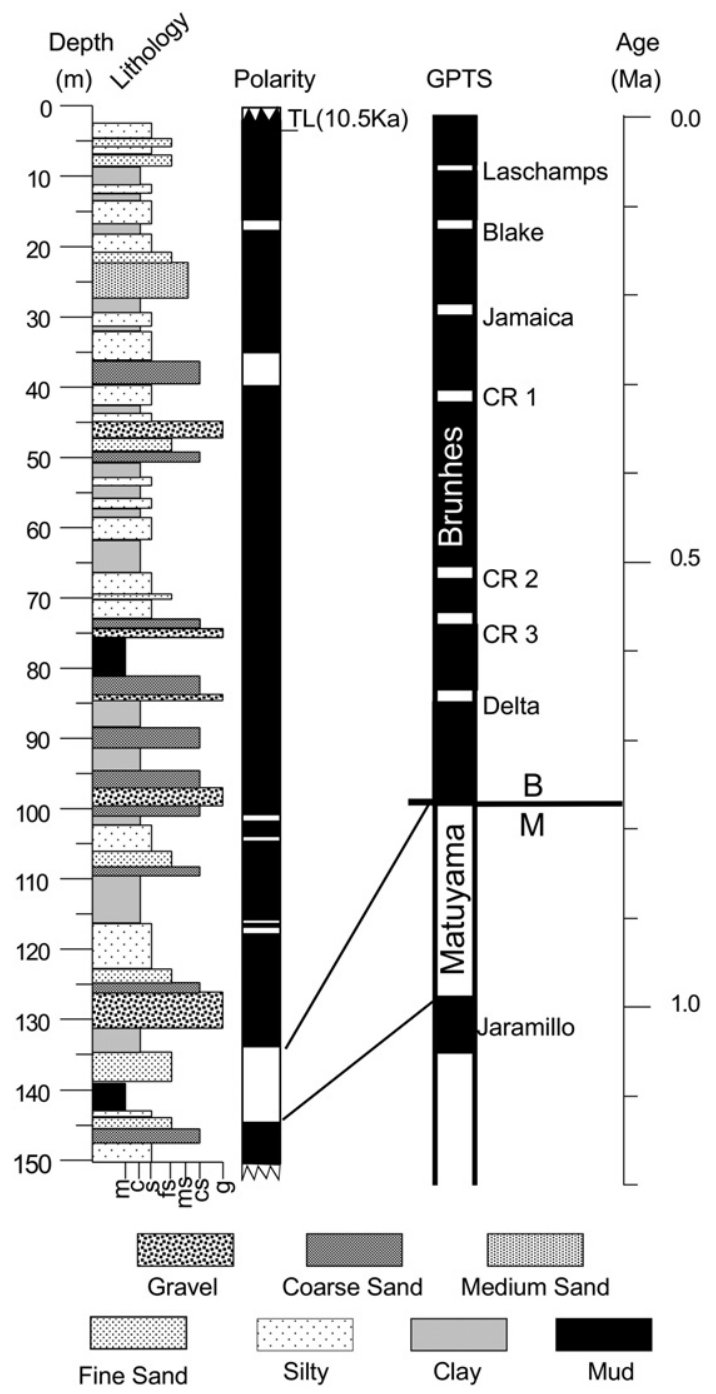

Fig. 3. Lithology and magnetostratigraphy of the Changping core sequence adapted from Cai et al. (2014), in which magnetostratigraphy of the core is correlated with the Geomagnetic Polarity Timescale (GPTS; Cande and Kent, 1995). Events/excursions in the Brunhes Chron are shown according to Champion et al. (1988); Worm (1997); Langereis et al. (1997); and Laj and Channell (2007).

Rosaceae, Ranunculaceae, Urtica and Ephedra. The main arboreal taxa were Pinus, Alnus, Corylus, Juglans, Pterocarya, Betula, Carpinus, Ulmus and Quercus, as well as other elements with low percentages. The main families and genera are shown in the pollen diagrams (Fig. 4). The pollen assemblage is characterized by a high percentage of herb and shrub taxa (average 95.5\%) and a low percentage of tree taxa (average $4.5 \%$ ). Artemisia (average $74.9 \%$ ), Chenopodiaceae (average $12.0 \%$ ) and Asteraceae (average 5.1\%) dominate the pollen assemblages throughout the whole sequence. Most of the tree pollen taxa comprise $<1.0 \%$ and some occur only in traces. The pollen concentration varies from 8.6 to 5528.4 grains/g. The ratio of arboreal pollen (AP) to nonarboreal pollen (NAP) ranges between 0 and 0.7 . Based on variations in the abundance of the dominant taxa and the AP/NAP ratios, the following pollen zones were determined (Fig. 4).

\subsection{Zone I ( 0.96-0.61 Ma; depth: 145-102 m)}

In this zone, arboreal pollen taxa, mainly derived from Ulmus, Quercus, Pinus, Corylus, Betula and Juglans, account for 0-30.5\%. Pinus constitutes $0-4.9 \%$ (mean of $1.3 \%$ ), while Ulmus fluctuates between 0 and $15.2 \%$ (mean of 5.5\%) and Quercus ranges between 0 and $8.5 \%$ (mean of 1.7\%). Other temperate deciduous broadleaved tree species 


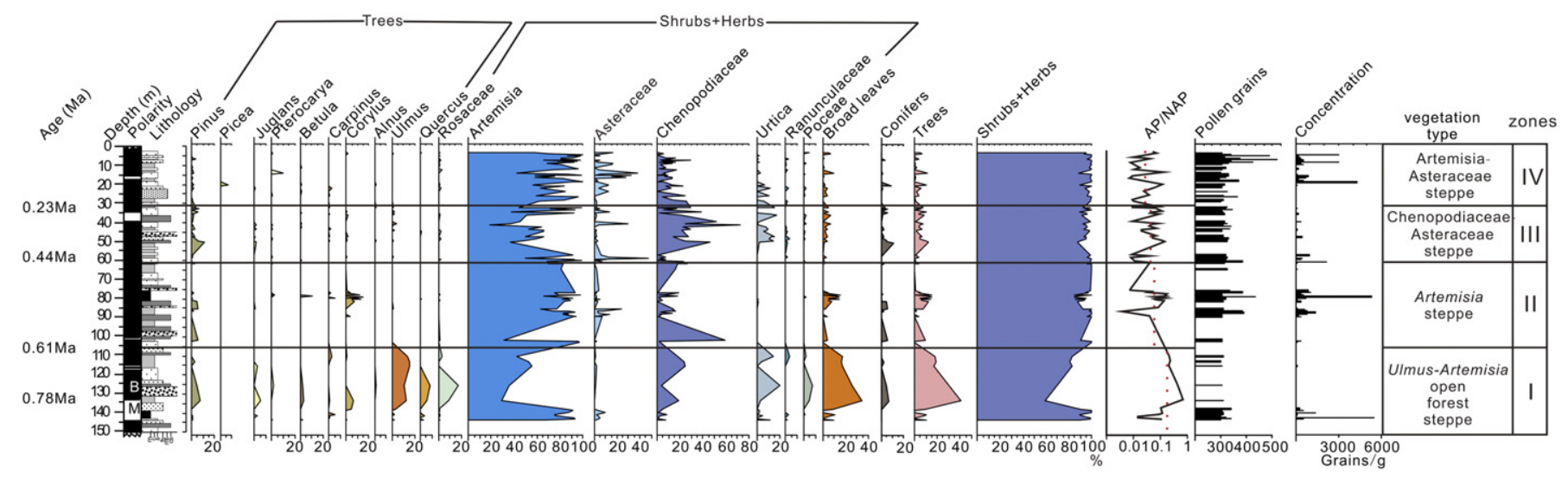

Fig. 4. Pollen percentage diagrams of the Changping core showing selected taxa and indices. (AP: arboreal pollen; NAP: nonarboreal pollen).

including Juglans, Alnus, Corylus and Betula are present in most samples in this zone. The nonarboreal pollen percentages are the lowest in the whole sequence (59.0-100\%, average of $88.1 \%$ ). Artemisia, Chenopodiaceae, and Urtica constitute $29.0-97.1 \%$ (average of $70.0 \%$ ), $0.8-24.5 \%$ (average of $8.7 \%$ ), and $0-19.5 \%$ (average of $4.3 \%$ ), respectively. Rosaceae and Asteraceae occur in moderately high percentages (each averaging $2.4 \%$ ). Other mesic and arid herbs appear with low and erratic percentages, including Poceae, Ephedra, Ranunculaceae, Brassicaceae and Apiaceae. The $\mathrm{AP} / \mathrm{NAP}$ ratio ranges between 0 and 0.7 with an average of 0.2 (Fig. 4).

\subsection{Zone II ( 0.61-0.44 Ma; depth: 102-76 m)}

This zone is characterized by markedly lower values of arboreal taxa ( $0-14.8 \%$, average of $5.1 \%)$ and a steady increase in nonarboreal taxa (85.0-100\%, average of $94.9 \%$ ). Broadleaved taxa including Ulmus, Quercus, Betula and Juglans show a sharp decline and almost disappear. However, Corylus is present and exhibits high numbers (0-14.8\%, average of $7.8 \%$ ) over the period from 0.47 to $0.48 \mathrm{Ma}$. Meanwhile, the proportion of the shrub taxon Rosaceae also displays a remarkable decrease to $0-1.3 \%$ (average of $0.17 \%$ ). The pollen of nonarboreal taxa including Artemisia (average of 82.7\%) and Asteraceae (average of $3.8 \%$ ) displays a remarkable increase compared with Zone I. Other mesic pollens including Poaceae and Urtica decreased and only occur in two samples within this zone. The AP/NAP ratio decreases and ranges between 0 and 0.18 with an average of 0.06 (Fig. 4).

\subsection{Zone III ( 0.44-0.23 Ma, depth: 76-40 m)}

This zone is characterized by an abrupt increase in Chenopodiaceae and Asteraceae in comparison with the preceding zone II; the former ranges from 0 to $72.7 \%$ (average $22.1 \%$ ) and the latter from 0 to $47.5 \%$ (average 6.0\%). Artemisia markedly declines to $14.3-37.2 \%$ of the total pollen, with an average of $29.5 \%$. Other mesic herbs and shrubs including Urtica (average of $4.0 \%$ ), Poaceae (average of $0.2 \%$ ) and Rosaceae (average of $0.4 \%$ ) show a slight increase in this zone. There is a gradual decline in arboreal taxa (0-12.6\%, average of 3.5\%). The levels of tree pollen in this zone, including Betula, Alnus and Quercus, are slightly lower compared with Zone II and comprise less than $1 \%$. The AP/NAP ratio decreases and ranges between 0 and 0.14 with an average of 0.04 (Fig. 4).

\subsection{Zone IV (0.23-0.01 Ma, depth: 40-0 m)}

The most striking feature of this zone is an abrupt increase in Artemisia (average of $77.9 \%$ ), whereas Chenopodiaceae declines to $10.2 \%$. Asteraceae continues to increase and reaches their maximum average percentage (6.3\%). The other mesic herb and shrub taxa, including Rosaceae and Urtica, maintain their trend of a gradual decrease. Tree pollen taxa continue to decline and reach the lowest average $(2.3 \%)$ within this zone. Betula, Alnus, Juglans, Ulmus and Quercus occasionally appear and show a slight decline compared with Zone III. The AP/NAP ratio ranges between 0 and 0.12 , reaching the lowest average (0.03) in this section (Fig. 4).

\section{Discussion}

\subsection{Vegetation history and paleoclimate trends}

According to modern surface pollen studies, Chenopodiaceae and Artemisia pollen taxa are generally over-represented relative to parent plants present in the vegetation (El-Moslimany, 1990; Ma et al., 2008). Small amounts ( $<30 \%)$ of arid Artemisia and Chenopodiaceae are usually regarded as been derived from exotic sources because of their high productivity (Li and Yan, 1990). Pinus is often overrepresented in pollen records because of its high pollen production and long-distance dispersal. A percentage of Pinus less than $30 \%$ in the pollen spectrum is generally regarded as exotic and likely to have originated from surrounding mountains (Denton and Karlen, 1973; Li and Yao, 1990; Wang et al., 1996). Percentages of Betula, Ulmus, and Poaceae pollen over $2.5 \%, 2 \%$, and 3-6\%, respectively, suggest that they exist in the vicinity (Tong et al., 1996; Zhao et al., 1998). Based on the distribution patterns of modern vegetation in the Beijing plain, the sporopollen spectra in the fluvio-lacustrine sediments record all communities in the plain and surrounding mountains (Vegetation Map Fig. 1c). We can expect that xeromorphic and mesic herbs such as Chenopodiaceae, Asteraceae, Artemisia, Urtica, Poaceae, Ranunculaceae, Brassicaceae and Apiaceae grew on the plain. Deciduous trees and shrubs such as Ulmus, Betula, Alnus, Quercus, Juglans and Rosaceae likely grew on the middle slope of the surrounding mountains, while Picea and perhaps Pinus were present on higher slopes of the surrounding mountains. Thus, the pollen record from the plain deposits is a plausible reflection of the evolution of the regional vegetation.

Temperature and humidity are the two most useful basic parameters for understanding the paleoclimate pattern of the East Asian Monsoon (Nie et al., 2013, 2014). In general, broadleaved trees, such as Ulmus, Betula, Alnus, Quercus and Juglans, indicate relatively warm conditions in a study area (warm temperate). Thus, the variation in the percentages of broadleaved trees may reflect temperature changes (Hilbig, 1995; Cai et al., 2013). The ratio of arboreal pollen (AP) to nonarboreal pollen (NAP) is used to indicate the density of tree cover. High values of the herbaceous taxa compared with the arboreal taxa are usually regarded as a proxy for dry conditions (White et al., 1997a,b; Wu et al., 2011; Cai et al., 2012). The zonation of sporopollen diagrams and index records in this paper show clear vegetation change and a 
long-term drying/cooling trend on the Beijing plain since the Middle Pleistocene.

The high percentages of Ulmus, Quercus, Rosaceae, Pinus and Juglans as well as the significant representation of Artemisia from $\sim 0.96$ to $0.61 \mathrm{Ma}$ (zone I) indicate that deciduous broadleaf forest-steppe dominated the Beijing plain. The precipitation was high during this period according to the AP/NAP ratio values. The higher percentages of broadleaved trees and the AP/NAP values suggest that the climate was optimal for vegetation during the period from 0.96 to $0.01 \mathrm{Ma}$. According to the pollen diagram, we infer that an Ulmus-Artemisia open forest-steppe environment with a mild and relatively wet climate existed during the period from $\sim 0.96$ to $0.61 \mathrm{Ma}$. Subsequently, the vegetation between 0.61 and $0.44 \mathrm{Ma}$ (zone II) was very different. The highest percentage of Artemisia and the abrupt decrease in the AP/ NAP values imply that an Artemisia-steppe was dominant and the climate became drier during this stage. Moreover, a decrease in the broadleaved trees suggests that temperatures synchronously fell ca. $0.6 \mathrm{Ma}$ ago. From 0.44 to $0.23 \mathrm{Ma}$ (zone III), the highest proportion of Chenopodiaceae and the lower percentage of Artemisia indicate that a Chenopodiaceae-Asteraceae steppe covered the plain. During this stage, the climate became much drier, which manifested in strong increases of xerophilous Chenopodiaceae and Asteraceae. A decreasing trend of the AP/NAP values provided further evidence of this drying pattern. From $0.23 \mathrm{Ma}$ (zone IV), the Beijing plain was covered by Artemisia-Asteraceae steppe. The climate may have changed to colder and drier conditions since the amount of tree pollen was reduced to its minimum while herbs reached their maximum. The lowest AP/NAP values and highest percentage of Asteraceae in the core confirm this interpretation.

The trends of vegetation cover decline and long-term climate drying revealed by this pollen record were also observed in other records. The long-term decrease in chemical weathering intensity suggested by the chemical index of alteration (CIA) values from the same core supports the pollen record (Fig. 5c; Cai et al., 2014). Records from other parts of the Beijing plain also corroborate our interpretations. Through a reconstruction of the vegetation change from the X5 core of the Beijing plain, Jiang (2013) suggested a stepwise decline of vegetation cover in the study area since $0.9 \mathrm{Ma}$, which indicates that the climate changed from warm and humid to cold and dry in the Middle Pleistocene (Fig. 5e). The pollen records obtained from the Tianzhu core of the Beijing plain indicate a cooling and drying trend since 0.8 Ma (Yao et al., 2007). The $\delta^{13} \mathrm{C}$ and $\delta^{18} \mathrm{O}$ values of deer enamel from Zhoukoudian decreased substantially from about $0.72 \mathrm{Ma}$, which indicates a trend of climate deterioration since the Middle Pleistocene (Gaboardi et al., 2005; Fig. 5f). These results all support the inferred transition from a relatively warm and humid climate to a cold and dry climate during 0.9-0 Ma in the Beijing plain. The drying trend in North China since the Middle Pleistocene has also been reported in other sites of North and East China such as the Huanghe drainage basin (Yang et al., 2006); the Nihewan Basin (Ao et al., 2010); the Loess Plateau (Sun, 2000; Ding et al., 2002; Xiong et al., 2010); and the Yangtze River (Zhang et al., 2013; Fig. 5h, i).

\subsection{Implication for Homo erectus occupation of North China}

Fossils attributed to Homo erectus attest to the occupation of the Beijing plain by hominids during the Middle and Late Pleistocene (Wu and Dong, 1985). Wu (2001) suggested that the earliest age for Homo erectus pekinensis was 0.58 Ma BP. Shen et al. (2001) performed ${ }^{230} \mathrm{Th} /{ }^{234} \mathrm{U}$ dating of the intercalated speleothem samples from the limestone cave occupied by Homo erectus in Zhoukoudian, China. They suggested that the age of the hominid fossils from the lower strata is at least 0.6 Ma. Liu and Wang (2004) recovered Homo erectus fossils from the cave deposits in Tangshan, Nihewan, and Zhoukoudian, as well as the deposits at the Homo erectus site in Chenjiawo. They found that the Homo erectus in all of these sites originated from the Early-Middle Pleistocene and flourished in MIS 16 (0.6 Ma) and the major interglacial period of the paleosol stage S5 (0.5 Ma). Using the cosmogenic ${ }^{26} \mathrm{Al} /{ }^{10} \mathrm{Be}$ method, Shen et al. (2009) obtained an age of Zhoukoudian Homo erectus appearance that is in the range of $0.68-0.78 \mathrm{Ma}$. The other early human records from Chenjiawo and Gongwangling of North China also show that Homo erectus appeared at approximately 0.65 Ma (Wang et al., 1997). Some studies indicated that early human evolution was significantly moderated by climate and environmental changes (Vrba et al., 1995; deMenocal, 2004; Maslin and Christensen, 2007). The relationship between climate and human evolution seems intuitive and indeed, environmental factors have been suggested as a driving force in hominin evolution by many authors (Vrba, 1985; Potts, 1996, 1998, 2013; Kingston, 2007; Maslin et al., 2014). Long-term shifts in climate can result in extreme and inconsistent environmental variability, which results in the selection of behavioral and morphological mechanisms of humans that enhance adaptive variability. Most environmental hypotheses of hominin
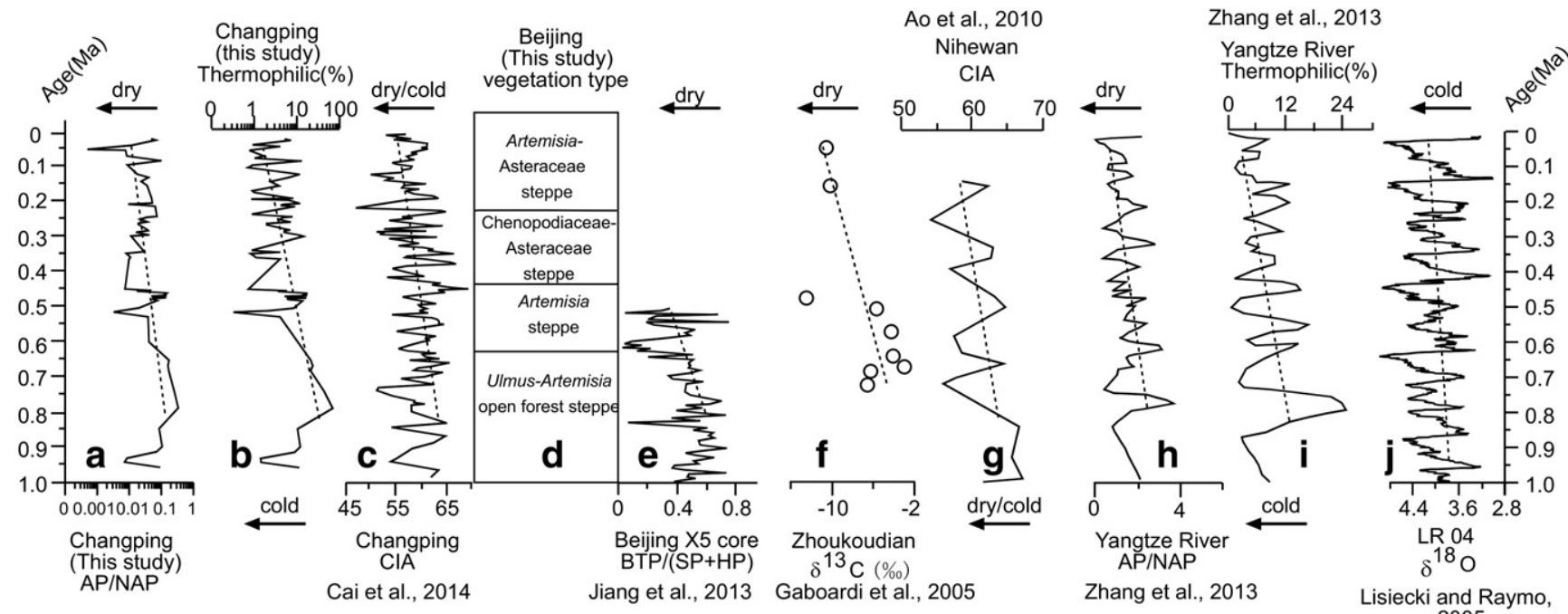

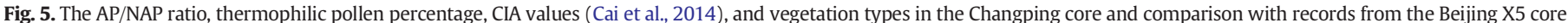

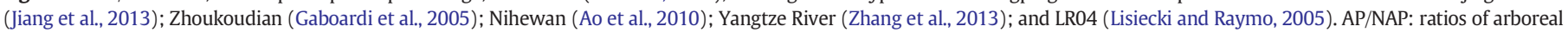
pollen to nonarboreal pollen; Thermophilic taxa: Ulmus + Betula+Quercus+Castanea+Juglans (\%). 
evolution are 'habitat-specific' in that they consider that fauna adapt to a specific environment (Maslin et al., 2014). The increased cooling and drying climate may have caused a change in the vegetation type, which would have had a strong impact on faunal distributions (Potts, 1998). Therefore, intensified aridification/cooling in North China would reduce tree cover and result in more open savanna grasslands, which may have promoted a prominent flourishing of savannaadapted early humans (Ao et al., 2010; Fig. 5g). The records from our core, the Tianzhu core (Yao et al., 2007) and the X5core (Jiang et al., 2013; Fig. 5e), both indicate a vegetation transition on the Beijing plain from forest-steppe to steppe at $\sim 0.6 \mathrm{Ma}$. The $\delta^{13} \mathrm{C}$ values of deer enamel from the Zhoukoudian site show behavioral changes in the deer at $\sim 0.55 \mathrm{Ma}$, which could be due to the vegetation shift to steppe (Gaboardi et al., 2005, Fig. 5f). The Chenjiawo hominids occupied an environment similar to that of the Gongwangling where the vegetation changed to a mixture of forest and steppe approximately 0.65 Ma ago (Wang et al., 1997). Moreover, the relatively "cold-climate-adapted" Paleoarctic fauna were not found until the time of the Chenjiawo (0.65 Ma) and Zhoukoudian $(0.5$ Ma) hominid relics (Wang et al., 1997). These results indicate that the vegetation and climate in North China experienced transitions during the Middle Pleistocene, where the cold and dry climate produced an abundance of open forest steppe instead of forest (Yuan et al., 1996; Wu et al., 2004; Jiang et al., 2013). This open forest steppe framework between 0.96 and 0.61 Ma may have provided a general setting for early human evolution. Early humans started to acclimatize themselves to a dryer and colder climate in North China (Shen et al., 2009). Then, after 0.61 Ma, the open forest steppe-adapted Homo erectus experienced a prominent flourishing with population growth and migration. Thus, the cold and dry climate during the Middle Pleistocene may have enhanced the occupation and flourishing of Homo erectus populations in open habitats of North China.

As shown in Fig. 5, the long-term decline in the AP/NAP and CIA ratios reflects a decrease in vegetation cover and chemical weathering in the Beijing plain. This is broadly consistent with the long-term cooling trend depicted in the benthic $\delta^{18} \mathrm{O}$ record (Lisiecki and Raymo, 2005, Fig. 5j) during the Middle Pleistocene. The global cooling induced a weakening of the East Asian Summer Monsoon (EASM), which transports moisture to North China from the Pacific Ocean (Passey et al., 2009; Miao et al., 2012, 2013). Thus, our result suggests that the long-term drying of the Beijing plain since the Middle Pleistocene might have been caused by long-term global cooling. Additional detailed long-term vegetation and climatic records from North China are needed to decipher the major forcing mechanisms of vegetation and climate change and the impact of these changes on Homo erectus colonization throughout the Middle and Late Pleistocene.

\section{Conclusion}

Pollen analysis of the core from the Beijing plain was used to create a high quality paleo-vegetation record during the Middle Pleistocene. The pollen record suggests that an open forest steppe dominated by Ulmus and Artemisia covered the Beijing region from 0.96 to $0.61 \mathrm{Ma}$. The vegetation changed from Artemisia-steppe between 0.61 and $0.44 \mathrm{Ma}$ to Chenopodiaceae-Asteraceae steppe between 0.44 and $0.23 \mathrm{Ma}$, and then to Artemisia-Asteraceae steppe after $0.23 \mathrm{Ma}$. The change in the vegetation indicates an increasing trend of drying and cooling in the Beijing plain during the Middle Pleistocene. This coincides with the Homo erectus colonization of North China during this period. The vegetation transition and cold and dry climates during the Middle Pleistocene may have enhanced the colonization and flourishing of Homo erectus populations in open habitats of North China. This general pattern of declining vegetation cover in the study area is consistent with climatic and environmental patterns in other regions in North China, which were probably influenced by global cooling during the Middle Pleistocene.

\section{Acknowledgments}

This study was co-supported by the Key Project (B) No.KZ201210028034 of Beijing Natural Science Foundation Project; NSFC grants (41301218, 40871017, 41371210); the China Postdoctoral Science Foundation (Grant No. 2014T70117, 2013M530714) and the Beijing Natural Science Foundation (8132021).

\section{References}

Ao, H., Deng, C.L., Dekkers, M.J., Sun, Y.B., Liu, Q.S., Zhu, R.X., 2010. Pleistocene environmental evolution in the Nihewan Basin and implication for early human colonization of North China. Quat. Int. 223-224, 472-478.

Cai, M.T., Fang, X.M., Wu, F.L., Miao, Y.F., Appel, E., 2012. Pliocene-Pleistocene stepwise drying of Central Asia: evidence from paleomagnetism and sporopollen record of the deep borehole SG-3 in the western Qaidam Basin, NE Tibetan plateau. Glob. Planet. Chang. 94, 72-81.

Cai, M.T., Wei, M.J., Xu, D.N., Miao, Y.F., Wu, F.L., Pan, B.L., 2013. Vegetation and climate changes during three interglacial periods represented in the Luochuan loesspaleosol section, on the Chinese Loess Plateau. Quat. Int. 296, 131-140.

Cai, M.T., Wei, M.J., Yang, Y.B., Wang, J.P., Xu, D.N., 2014. Long-term cooling/drying record of North China since the Middle Pleistocene from geochemical evidence of a $150 \mathrm{~m}$ deep drill core, Beijing plain, China. Quat. Int. 349, 419-427.

Cande, S.C., Kent, D.V., 1995. Revised calibration of the geomagnetic polarity timescale for the Late Cretaceous and Cenozoic. J. Geophys. Res. 100, 6093-6095.

Champion, D.E., Lanphere, M.A., Kuntz, M.A., 1988. Evidence for a new geomagnetic reversal from lava flows in Idaho: discussion of short polarity reversals in the Brunhes and late Matuyama polarity chrons. J. Geophys. Res. 93, 11667-11680.

Compilatory Commission of Vegetation of China, 1980. Vegetation of China. Science Press, Beijing, pp. 932-955 (in Chinese)

deMenocal, P.B., 1995. Plio-Pleistocene African climate. Science 270, 53-59.

deMenocal, P.B., 2004. African climate change and faunal evolution during the PliocenePleistocene. Earth Planet. Sci. Lett. 220, 3-24.

Denton, G.H., Karlen, W., 1973. Holocene climatic variations-their pattern and possible cause. Quat. Res. 3, 155-205.

Ding, Z.L., Derbyshire, E., Yang, S.L., Yu, Z.W., Xiong, S.F., Liu, T.S., 2002. Stacked 2.6Ma grain size record from the Chinese loess based on five sections and correlation with the deep-sea $\mathrm{d}^{18} \mathrm{O}$ record. Paleoceanography 17, 1033. http://dx.doi.org/10.1029/ 2001 PA000725.

El-Moslimany, A.P., 1990. Ecological significance of common nonarboreal pollen: examples from drylands of the Middle East. Rev. Palaeobot. Palynol. 64, 343-350.

Gaboardi, M., Deng, T., Wang, Y., 2005. Middle Pleistocene climate and habitat change at Zhoukoudian, China, from the carbon and oxygen isotopic record from herbivore tooth enamel. Quat. Res. 63, 329-338.

Goldberg, P., Weiner, S., Bar-Yosef, O., Xu, Q.Q., Liu, J.Y., 2001. Site formation processes at Zhoukoudian, China. J. Hum. Evol. 41, 483-530.

Hilbig, W., 1995. The Vegetation of Mongolia. SPB Academic Publishing, Amsterdam, pp. 236-238.

Ji, H.X., 1989. Geographic distribution and environment of mammal fauna. In: Shi, Y.F. Cui, Z.J., Li, J.J. (Eds.), Quaternary Glaciations and Environment in Eastern China. Science Press, Beijing (in Chinese).

Jia, L., 1980. Early Man in China. Foreign Languages Press, Beijing.

Jiang, H.C., Guo, G.X., Cai, X.M., Xu, H.Y., Ma, X.L., Zhong, N., Li, Y.H., 2013. A pollen record of the Mid-Pleistocene transition from Beijing, North China. J. Quat. Sci. 28 (7), $720-728$.

Kingston, J.D., 2007. Shifting adaptive landscapes: progress and challenges in reconstructing early hominid environments. Am. J. Phys. Anthropol. Suppl. Yearb. Phys. Anthropol. 134 (Issue Suppl. 45), 20-58.

Kong, Z.C., Du, N.Q., Wu, Y.S., et al., 1981. Discussion on the evolution of natural environment around the Sinanthropus' living period based on pollen analysis. Chin. Sci. Bull. 26, 1065-1067 (in Chinese).

Kong, Z.C., Du, L., Wu, Y.S., Yu, Q., Yi, M., Ren, Z., 1985. Vegetational and climatic changes since Paleogene at Zhoukoudian and its adjacent regions. In: Wu, R.K., Ren, M.E., Zhu, X.M., Yang, Z.G., Hu, C.K., Kong, Z.C., Xie, Y.Y., Zhao, S.S. (Eds.), Multi-Disciplinary Study of the Peking Man Site at Zhoukoudian. Science Press, Beijing (in Chinese).

Laj, C., Channell, J.E.T., 2007. Geomagnetic excursions. Treatise on Geophysics. 5 pp. 373-416.

Langereis, C.G., Dekkers, M.J., de Lange, G.J., Paterne, M., Santvoort, P.J.M., 1997. Magnetostratigraphy and astronomical calibration of the last 1.1 Myr from an eastern Mediterranean piston core and dating of short events in the Brunhes. Geophys. J. Int 129, 75-94.

Li, W.Y., Yan, S., 1990. Research of Quaternary palynology, Chaiwopu basin. In: Shi, Y.F. (Ed.), Quaternary Climatic Change and Hydrologic Geological Events of Chaiwopu Basin, Xinjiang Province. Oceanic Press, Beijing, pp. 46-72 (in Chinese)

Li, W.Y., Yao, Z.J., 1990. A study on the quantitative relationship between Pinus pollen in surface sample and Pinus vegetation. Acta Bot. Sin. 32, 943-950 (in Chinese).

Lisiecki, L.E., Raymo, M.E., 2005. A Plio-Pleistocene stack of 57 globally distributed benthic $\mathrm{d}^{18} \mathrm{O}$ records. Paleoceanography $20,1003-1017$. 
Liu, J.L., Wang, W.M., 2004. Homo erectus pekinensis's age and environment-with discussion on the relationship among Homo erectus from Beijing, Nanjing and Chenjiawo. Sci. China Earth Sci. 47, 68-77.

Ma, Y.Z., Liu, K.B., Feng, Z.D., Sang, Y.L., Wang, W., Sun, A.Z., 2008. A survey of modern pollen and vegetation along a south-north transect in Mongolia. J. Biogeogr. 35, 1512-1532.

Maslin, M.A., Christensen, B., 2007. Tectonics, orbital forcing, global climate change, and human evolution in Africa: introduction to the African paleoclimate special volume. J. Hum. Evol. 53, 443-464.

Maslin, M.A., Brierley, C.M., Milner, A.M., Shultz, S., Trauth, M.H., Wilson, K.E., 2014. East African climate pulses and early human evolution. Quat. Sci. Rev. 101, 1-17.

Miao, Y.F., Herrmann, M., Wu, F.L., Yan, X.L., Yang, S.L., 2012. What controlled Mid-Late Miocene long-term aridification in Central Asia? Global cooling or Tibetan Plateau uplift: a review. Earth-Sci. Rev. 112 (3-4), 155-172.

Miao, Y.F., Fang, X.M., Wu, F.L., Cai, M.T., Song, C.H., Meng, Q.Q., Xu, L., 2013. Late Cenozoic continuous aridification in the western Qaidam Basin: evidence from sporopollen records. Clim. Past 9, 1485-1508. http://dx.doi.org/10.5194/cpd-9-1485-2013.

Moore, P.D., Webb, J.A., Collinson, M.E., 1991. Pollen Analysis. Blackwell Science, Oxford, pp. 39-62.

Nie, J.S., Song, Y.G., King, J.W., Zhang, R., Fang, X.M., 2013. Six million years of magnetic grain-size records reveal that temperature and precipitation were decoupled on the Chinese Loess Plateau during 4.5-2.6 Ma. Quat. Res. 79, 465-470.

Nie, J.S., Stevens, T., Song, Y.G., King, J.W., Zhang, R., Ji, S.C., Gong, L.S., Cares, D., 2014 Pacific freshening drives Pliocene cooling and Asian monsoon intensification. Sci. Rep. 4, 5474. http://dx.doi.org/10.1038/srep05474. 6.

Passey, B.H., Ayliffe, L.K., Kaakinen, A., Zhang, Z., Eronen, J.T., Zhu, Y., Zhou, L., Cerling, T.E., Fortelius, M., 2009. Strengthened East Asian summer monsoons during a period of high-latitude warmth? Isotopic evidence from Mio-Pliocene fossil mammals and soil carbonates from northern China. Earth Planet. Sci. Lett. 277, 443-452.

Potts, R., 1996. Evolution and climate variability. Science 273, 922-923.

Potts, R., 1998. Environmental hypotheses of hominin evolution. Yearb. Phys. Anthropol. $41,93-136$

Potts, R., 2013. Hominin evolution in settings of strong environmental variability. Quat. Sci. Rev. 73, 1-13

Shen, G.J., Ku, T.L., Cheng, H., Edwards, R.L., Yuan, Z.X., Wang, Q., 2001. High-precision Useries dating of Locality 1 at Zhoukoudian, China. J. Hum. Evol. 41 (6), 679-688.

Shen, G.J., Gao, X., Granger, D.E., 2009. Age of Zhoukoudian Homo erectus determined with ${ }^{26} \mathrm{Al} /{ }^{10} \mathrm{Be}$ burial dating. Nature 458, 198-200.

Song, Z.C., Zheng, Y.H., Li, M.Y., 1999. Fossil spores and pollen of China. The Late Cretaceous and Tertiary spores and pollen vol. 1. Science Press, Beijing (in Chinese).

Sun, J.M., 2000. Stratigraphic evidence for the uplift of the Tibetan Plateau between $\sim 1.1$ and $\sim 0.9$ myr ago. Quat. Res. 54, 309-320.

Tong, G.B., Yang, X.D., Wang, S.M., Xia, L.H., 1996. Sporo-pollen dissemination and quantitative character of surface sample of Manzhouli-Dayangshu region. Acta Bot. Sin. 38 (10), 814-821 (in Chinese with English abstract).

Vrba, E.S., 1985. Environment and evolution: alternative causes of the temporal distribution of evolutionary events. S. Afr. J. Sci. 81, 229-236.

Vrba, E.S., Denton, G.H., Partridge, T.C., Burckle, L.H., 1995. Paleoclimate and Evolution, with Emphasis on Human Origins. Yale University Press, New Haven.

Wang, F.X., Qian, N.F., Zhang, Y.L., 1995. Pollen Flora of China. Science Press, Beijing (in Chinese).

Wang, F.Y., Song, C.Q., Sun, X.J., 1996. Study on surface pollen in middle Inner Mongolia, China. Acta Bot. Sin. 38, 902-909.

Wang, H., Ambrose, S.H., Liu, L.C.J., Follmer, L.R., 1997. Paleosol stable isotope evidence for early hominid occupation of East Asian temperate environments. Quat. Res. 48, 228-238.
White, J.M., Ager, T.A., Adam, D.P., Leopold, E.B., Liu, G., Jetté, H., Schweger, C.E., 1997a. An 18 million year record of vegetation and climate change in northwestern Canada and Alaska: tectonic and global climatic correlates. Palaeogeogr. Palaeoclimatol. 130, 293-306.

White, J.M., Ager, T.A., Adam, D.P., Leopold, E.B., Liu, G., Jette, H., Schweger, C.E., 1997b. An 18 million year record of vegetation and climate change in northwestern Canada and Alaska: tectonic and global climate correlates. Palaeogeogr. Palaeoclimatol. 130, 293-306.

Worm, H.U., 1997. A link between geomagnetic reversals and events and glaciations. Earth Planet. Sci. Lett. 147, 55-67.

$\mathrm{Wu}, \mathrm{X} . Z ., 2001$. A review of studies on the human origination with expectation of palaeoanthropology in China. Prog. Earth Sci. 5 (16), 629-633 (in Chinese).

Wu, R.K., Dong, X., 1985. Retrospect and Prospect of the Study of Peking Man. In: Wu, R.K., Ren, M.E., Zhu, X.M., Yang, Z.G., Hu, C.K., Kong, Z.C., Xie, Y.Y., Zhao, S.S. (Eds.), MultiDisciplinary Study of the Peking Man Site at Zhoukoudian. Science Press, Beijing (in Chinese).

Wu, R.K., Ren, M.E., Zhu, X.M., Yang, Z.G., Hu, C.K., Kong, Z.C., Xie, Y.Y., Zhao, S.S., 1985. Multi-Disciplinary Study of the Peking Man Site at Zhoukoudian. Science Press, Beijing (in Chinese).

Wu, F.L., Fang, X.M., Ma, Y.Z., An, Z.S., Li, J.J., 2004. A 1.5 Ma sporopollen record of paleoecologic environment evolution in the central Chinese Loess Plateau. Chin. Sci. Bull. 49, 295-302.

Wu, F.L., Fang, X.M., Herrmann, M., Mosbrugger, V., Miao, Y.F., 2011. Extended drought in the interior of Central Asia since the Pliocene reconstructed from sporopollen records. Glob. Planet. Chang. 76, 16-21.

Xi, Y.Z., Ning, J.C., 1994. Pollen morphology for arid-semiarid area, China. Yushania 11, 119-191.

Xiong, S.F., Ding, Z.L., Zhu, Y.J., Zhou, R., Lu, H.J., 2010. A 6 Ma chemical weathering history, the grain size dependence of chemical weathering intensity, and its implications for provenance change of the Chinese loess-red clay deposit. Quat. Sci. Rev. 29, 1911-1922.

Yang, S.Y., Li, C.X., Cai, J.G., 2006. Geochemical compositions of core sediments in eastern China: implication for Late Cenozoic palaeoenvironmental changes. Palaeogeogr. Palaeoclimatol. 229, 287-302.

Yao, Y.F., Ye, C., Kou, X.Y., Xu, J.X., Jia, S.M., Du, N.Q., Li, C.S., 2007. Vegetation succession and climate changing since the late Pliocene in Tianzhu region in Beijing. J. Palaeogeogr. 9, 45-58 (in Chinese with English abstract).

Yuan, B.Y., Zhu, R.X., Tian, W.L., Cui, J.X., Li, R.Q., Wang, Q., Yan, F.H., 1996. The age, subdivision and correlation of Nihewan Group. Sci. China Earth Sci. 26, 67-76 (in Chinese)

Zhang, Y., Tang, Z.W., 2007. Discussion on the paleoenvironment of the Peking Man site. Acta Anthropol. Sin. 26, 34-44.

Zhang, Y.D., Wang, J.P., Wei, M.J., Zhang, B., Zhou, R., 2012. Correlation between the content of different grain size and magnetic susceptibility in core Changping. Acta Sedimentol. Sin. 30 (3), 572-578 (in Chinese with English abstract).

Zhang, P., Miao, Y.F., Zhang, Z.Y., Lu, S.M., Zhang, Y.J., Chen, H.G., Li, X.Q., Miao, Q.Y., Feng, W.L., Ou, J., Gong, X.L., Jiang, B., Li, W., 2013. Late Cenozoic sporopollen records in the Yangtze River Delta, East China and implications for East Asian summer monsoon evolution. Palaeogeogr. Palaeoclimatol. 388, 153-165.

Zhao, J.B., Yue, Y.L., Yue, M., 1998. A study on the sporeepollen assemblage of modern oak forests in Qinling Mountains and loess area. J. Xi'an Eng. Univ 20, 46-50 (in Chinese).

Zhu, YZ. Zhou, M.Z, 1994. The Asian monsoon variation and the habituation environment of fossil man in Northern China. Catena 22, 121-131. 